\title{
Retratando el Madrid de la Guerra Civil. Santos Yubero en el Archivo Regional de la Comunidad de Madrid $^{1}$
}

\author{
Beatriz DE LAS HERAS \\ bheras@hum.uc3m.es \\ Víctor MORA \\ moravmora@gmail.com \\ Universidad Carlos III de Madrid. Departamento de Humanidades
}

Recibido: Octubre 2014

Aceptado: Noviembre 2014

Resumen: Trabajar con el fondo de Santos Yubero que se conserva en el Archivo Regional de la Comunidad de Madrid es acercarse a la memoria visual de la ciudad de Madrid del siglo XX a través de medio millón de fotografías tomadas entre los años 20 y 70 . El artículo que se presenta es un estudio de aquellas instantáneas que retratan la capital de España durante la Guerra Civil Española (1936-1939) en los tres espacios que se abrieron en la capital tras la sublevación de julio: frente, retaguardia y retaguardia militar. Tras mostrar los resultados de la catalogación de las fotografías (catalogación que se ha realizado priorizando al asunto retratado), analizaremos la repercusión que tuvo el trabajo de Santos Yubero durante este período. Para ello estudiaremos las instantáneas publicadas en los seis periódicos y diarios en los que trabajó durante el conflicto: ABC (edición Madrid), Ahora, Crónica, La Libertad, La Voz y Mundo Gráfico, tanto en solitario como firmando con un sello colaborativo junto a los hermanos Benítez Casaux. Finalmente, reflexionaremos sobre algunas características que tienen las fotografías de Yubero como documentos para aproximarse al acontecimiento que puede considerarse eje vertebrador del siglo pasado en España.

Palabras clave: Catalogación; Fondo fotográfico; Fotografía documental; Guerra Civil Española; Martín Santos Yubero; Memoria visual; Prensa.

1 Este artículo se ha escrito en el marco del Proyecto de Investigación de la Dirección General de Investigación Científica y Técnica del Ministerio de Economía y Competitividad del Gobierno de España: "La fotografía como documento para la Historia. Descubriendo el Madrid de la Guerra Civil a través de la mirada de Martín Santos Yubero" (HAR2012-35514) del Instituto de Cultura y Tecnología de la Universidad Carlos III de Madrid, tras convocatoria competitiva del Ministerio de Economía y Competitividad. 


\title{
Photographing Madrid during the Spanish Civil War. Santos Yubero's Photographs from the Archivo Regional de la Comunidad de Madrid
}

\begin{abstract}
The half a million photographs taken between the 20's and the 70's by Santos Yubero and kept in the "Archivo Regional de la Comunidad de Madrid" allow us to approach the visual memory of the city of Madrid during the 20th century.

This paper presents a study of the photographs that profile Madrid during the Spanish Civil War (1936-1939) in the three different spaces opened in the capital after the uprising of July: the front, the rear and the military rear.

After presenting the results of the catalogued photographs (taking into account the captured matter), the effect of the work of Santos Yubero during the Spanish Civil War will be analyzed. To do so, we will study the photographs published in the six different newspapers where Santos Yubero worked during the conflict: ABC (Madrid edition), Ahora, Crónica, La Libertad, La Voz and Mundo Gráfico. This work was made both alone and signing with the photographic agency that Santos Yubero created with Benítez-Casaux brothers.

Finally, we will reflect on some characteristics that the photographs of Yubero have as documents to approach the Spanish Civil War.
\end{abstract}

Keywords: Cataloging; Documentary photography; Martín Santos Yubero; Photographic Collection; Press; Spanish Civil War; Visual Memory.

\section{INTRODUCCIÓN}

En el año 2010 Publio López Mondejar comisarió una exposición sobre la obra de Martín Santos Yubero descubriendo un patrimonio visual de gran interés para la memoria del Madrid del siglo XX. A través de las fotografías de este profesional, que forma parte de la segunda generación de fotoperiodistas españoles, podemos hacer un recorrido visual por 50 años de la historia contemporánea de España desde una perspectiva holística: se interesó por la vida política, económica, cultural y social de la capital de Alfonso XIII, II República, Guerra Civil y Franquismo. En este artículo analizaremos el conjunto fotográfico que se conserva en el Archivo Regional de la Comunidad de Madrid y que retrata la vida en el frente y la retaguardia en la capital del ¡No pasarán! durante el acontecimiento más relevante del siglo pasado: la Guerra Civil Española.

Pero no nos acercaremos a este patrimonio desde su valor como ilustración sino que estudiaremos la colección para, tras un análisis pormenorizado, entender cómo se empleó la fotografía como canal o vía de comunicación entre la autoridad y la ciudadanía durante el período 1936-1939.

El primer paso es entender que la fotografía no muestra la realidad. En todo caso, muestra realidades. Si creemos que la fotografía es un espejo de la realidad erramos pues en ella se muestra lo que el operador de cámara, bajo su criterio o influido por un comitente, quiere mostrar en el instante en que encuadra (atendiendo a motivaciones de orden estético, cultural, ideológico o político) y 
apartando otras muchas posibilidades que se presentan como realidades veladas al lector pero que pueden dejar su huella en la instantánea. Hay una segunda intervención, que es la de la censura de los medios, característica del período estudiado, y hasta una tercera: la del canal por el que discurre la imagen. Comitente, autor, censor y medio se convierten, por tanto, en filtros de la realidad, al que se une un último: el lector, que puede (o no) compartir las coordenadas espacio-temporales del fotógrafo. Todos estos actores intervienen, de alguna forma, en la fotografía a través del encargo, producción, distribución o lectura.

Esta manipulación sobre la realidad a través de su consolidación en lo visual tiene una doble utilidad: en las coordenadas espacio-temporales en las que se toma como arma propagandística (de manos de los aliados) y arma de destrucción (en manos enemigas), y, en coordenadas temporales diferentes, como fuente para la Historia. Por tanto, la aparente visibilidad de la fotografía es, en algunos casos, eso: apariencia. Ninguna herramienta ha silenciado más para la creación de memoria, memorias o desmemoria que la fotografía en manos de la autoridad que pretende velar realidades: si no está en la fotografía, entonces no fue en la Historia. Si está en la fotografía, entonces fue, indiscutiblemente, en la Historia.

$Y$ este es el objetivo final "Descubriendo el Madrid de la Guerra a través de la mirada de Santos Yubero", proyecto de investigación del Plan Nacional I+D (Subprograma de Proyectos de Investigación Fundamental no Orientada) del Ministerio de Economía y Competitividad cuyos primeros resultados avanzamos en este artículo que hemos dividido en tres partes.

En la primera presentaremos el proyecto de investigación, destacando los objetivos, la perspectiva desde la que se encara y las fases de trabajo, al margen de justificar la razón por la que seleccionemos la obra fotográfica de Martín Santos Yubero.

La segunda parte del artículo está dedicada al estudio del fondo, formado por casi 500.000 fotografías, que se conserva, desde el año $1995 \mathrm{y}$, tras su compra al fotógrafo en 1988, en el Archivo Regional de la Comunidad de Madrid. Unas 2.700 instantáneas fueron tomadas en Madrid capital durante la guerra y son el objeto del estudio. Tras un análisis pormenorizado de cada unidad visual y catalogación del conjunto, realizamos un estudio (del que ofrecemos los resultados) atendiendo a la temática representada en los tres espacios que se abrieron en la ciudad: frente, retaguardia y retaguardia militar.

Finalmente, en la tercera parte, mostraremos los primeros resultados del trabajo directo con las instantáneas. En primer lugar contextualizando el espacio en el que se mostraron durante la contienda, ya fuera las fotografías firmadas por él como las que se publicaron bajo el sello Yubero-Casaux: ABC, Ahora, Crónica, La Libertad, La Voz y Mundo Gráfico. Como ejemplo de las posibilidades de estudio que tiene la colección analizaremos algunos ejemplos visuales en los que se demuestra que la fotografías, siempre que se trascienda la vista y se proponga la 
mirada, siempre que se la interrogue y escudriñe, pueden desvelar las estrategias y los usos que se hicieron de ellas.

\section{DESCUBRIENDO EL MADRID DE LA GUERRA A TRAVÉS DE LA MIRADA DE SANTOS YUBERO}

La fotografía supone un corte en el espacio y en el tiempo por lo que congela en un instante la memoria de lo fotografiado. Partiendo de este punto, y teniendo en cuenta que es un documento de trabajo para el historiador por su alto contenido de autentificidad y que puede esconder un mensaje socio-político que pase desapercibido tras una mirada apresurada, el proyecto "La fotografía como documento para la Historia. Descubriendo la Guerra Civil a través de la mirada de Martín Santos Yubero" (HAR2012-35514) se enfrenta al análisis de la colección de fotografías que Martín Santos Yubero tomó durante la Guerra Civil Española (19361939) y que se conserva en el Archivo Regional de la Comunidad de Madrid.

A partir de una perspectiva transdisciplinar, hemos enfrentado el proyecto, que se encuentra en el final de su segundo año de desarrollo, abarcando los distintos trabajos que afronta el historiador: el teórico-metodológico (propio del conocimiento formal, que pretende proporcionar los fundamentos metodológicos y las herramientas necesarias que se emplearán, con posterioridad, en la aplicación visual), al análisis del contexto (para poder situar el marco espacio-temporal de las fotografias), la heurística o búsqueda en archivo (tradicional tarea del investigador que nos permite conocer las fotografías, cómo pudo desarrollar el trabajo el fotógrafo y cuáles fueron sus motivaciones e intenciones a la hora de tomar unas instantáneas y no otras) y la experiencia de laboratorio, es decir, el trabajo directo con una selección de imágenes, tras una catalogación y análisis de cada unidad fotográfica.

¿Por qué Yubero? Miembro de la segunda generación de reporteros gráficos españoles, Martín Santos Yubero (1903-1994) es uno de los más importantes cronistas gráficos de la España del siglo XX (López Mondéjar, 2010). A través de su mirada podemos rescatar sucesos y acontecimientos desde los años 20, cuando realizó sus primeros reportajes para La Nación, invitado por su director Manuel Delgado Barreto, con una Kodak de cajón. Compaginó su trabajo como redactor de este periódico a partir de 1927 con el de fotógrafo libre que publicó fotografías en medios de distinta tendencia ideológica: Ahora, ABC, Estampa, La Tierra, Ya o $L u z$, empleando una Rodeston alemana 10x15. En 1933 se incorporó al Diario de Madrid, momento en el que comenzó a combinar el uso de su cámara de gran formato con una Contax de $35 \mathrm{~mm}$, y en 1935 se hizo cargo del servicio gráfico de $Y a$. Dadas las dificultades laborales, sobre todo por la carencia de material fotográfico (de hecho tuvo que volver a trabajar con sus cámaras de placas), durante la Guerra Civil Española se asoció con los hermanos Benítez Casaux con los que creó una agencia que envió material a $A B C$ (edición Madrid), Ahora, 
Crónica, La Libertad, La Voz y Mundo Gráfico. Con la llegada del Franquismo, Yubero recuperó su carnet de fotógrafo y retomó su trabajo en $Y a$ dirigiendo a alguno de los profesionales más destacados de la tercera generación de fotoperiodistas españoles, entre los que destaca Gabriel Carvajal, Luis Milla, Lucio Soriano, Ignacio Teresa y Sanz Bermejo. En el año 1975 se jubiló pensando en la necesidad de conservar su legado visual y comenzó negociaciones con la Agencia Efe para que compraran su obra. Finalmente fue la Comunidad de Madrid la institución que se hizo cargo de su legado visual.

\section{YUBERO EN EL FONDO FOTOGRÁFICO DEL ARCHIVO REGIONAL DE LA COMUNIDAD DE MADRID}

En el Archivo Regional de la Comunidad de Madrid se conservan 489.785 fotografías en distintos soportes (placas de vidrio, nitrato de celulosa, acetato de celulosa y poliéster y papel), hoy escaneados, tomados por Yubero a lo largo de sus más de 50 años como fotógrafo profesional. Estas imágenes fueron adquiridas por la institución el 20 de junio de 1988, después de dos años de negociaciones capitaneadas en su origen por el Centro Regional de Conservación del Patrimonio. $\mathrm{Su}$ traslado definitivo se produjo el 7 de junio de 1995 tras su custodia en la Dirección General de Medios de Comunicación en Presidencia de la Comunidad de Madrid. El fondo está catalogado (ES.28079 ARCM/30), siguiendo la catalogación original del fotógrafo, con signaturas que van desde la 000001 a la 046001.

De entre este total, más de 2.700 son instantáneas que conservan la imagen de espacios y personajes, sucesos y acontecimientos, de la ciudad de Madrid capital ${ }^{2}$, entre el 18 de julio de 1936 y el 1 de abril de 1939, por lo que hemos incluido fotografías de los primeros días tras la entrada de las tropas sublevada en la ciudad.

Tras el análisis de cada unidad visual (De las Heras, 2012:89-96), las fotografías fueron catalogadas en función de la temática o el asunto representado. El $10.97 \%$ de las instantáneas está tomado en el frente, $76.37 \%$ en la retaguardia y el $5.20 \%$ en la retaguardia militar, espacio de la retaguardia ocupado por lo militar durante la contienda. Un $7.45 \%$ de las instantáneas muestra la imagen de los primeros días de una ciudad tomada por los sublevados tras la contienda. El resultado pormenorizado de cada espacio, teniendo en cuenta el asunto retratado, es el siguiente:

\footnotetext{
${ }^{2}$ Entendiendo por ciudad los 7.775.276 metros cuadrados del denominado viejo Madrid, los 15.164.724 metros cuadrados del ensanche y los 43.816 .482 metros cuadrados del extrarradio, tal y como se definía en la Oficina Municipal de Información sobre la ciudad (Ayuntamiento de Madrid, 1929).
} 


\section{a. FRENTE}

Tabla I. Asuntos retratados en el frente

\begin{tabular}{|l|l|}
\hline \multicolumn{1}{|c|}{ Asunto } & \multicolumn{1}{c|}{ Núm. de fotografías } \\
\hline Personajes & $\mathbf{2 4}$ \\
\hline Mujer & 6 \\
\hline Guardias e imaginarias & 5 \\
\hline Preparando el combate & $\mathbf{3 8}$ \\
\hline Escenas bélicas & 17 \\
\hline Comunicaciones & 6 \\
\hline Adiestramiento militar & 10 \\
\hline Víctimas & 12 \\
\hline Tareas cotidianas & $\mathbf{3 8}$ \\
\hline Asueto & $\mathbf{1 0 4}$ \\
\hline
\end{tabular}

De entre el total de fotografías que fueron realizadas por Yubero en primera línea destacan por número cuatro temáticas diferentes: retrato de "Personajes", "Preparando el combate", "Tareas cotidianas" y, con mucha diferencia, "Asueto", que supone un $9.23 \%, 14.61 \%, 14.61 \%$ y $40 \%$, respectivamente, sobre el número de las tomadas en este espacio.

La alta cifra relativa a instantáneas que muestran a los milicianos en momentos relajados antes o tras la batalla tiene una explicación clara: para fotografiar en el frente era necesario solicitar un permiso específico al jefe del batallón correspondiente, permiso que solía concederse a un grupo numeroso de fotógrafos al mismo tiempo y en un espacio reducido, con lo que el resultado era muy similar entre los profesionales $\mathrm{y}$, por tanto, poco interesante. Al margen del interés o desinterés que Yubero tuviera sobre el retrato de batalla o las dificultades de laburo, lo que es indiscutible es que se acerca al espacio del frente desde una perspectiva de lo cotidiano, de la vida de los milicianos en la primera línea en el momento en el que disfrutaban de charlas, lectura, juegos o de acciones relacionadas con la cuidado personal o de su espacio, como se muestra en las siguientes instantáneas. La Figura 1 retrata un grupo de soldados en una trinchera posando junto a una guitarra el 1 de enero de 1938 y la Figura 2, no datada, en la que los milicianos leen el periódico. 


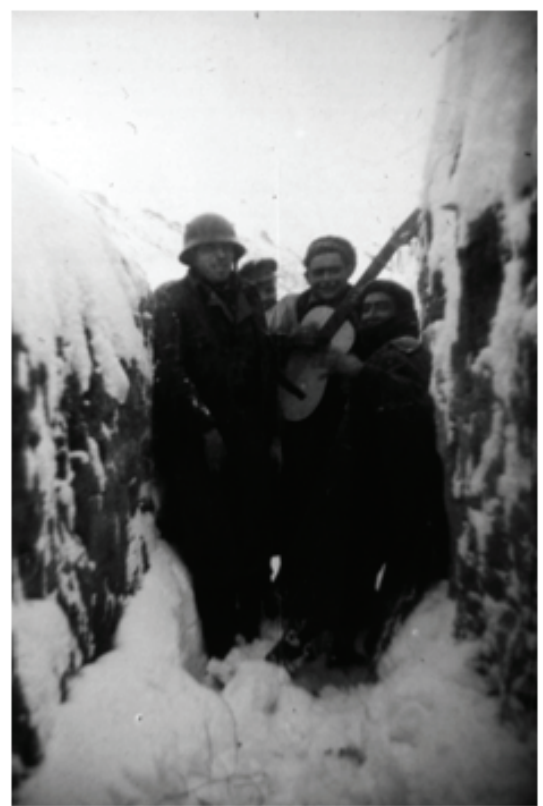

Figura 1. Trinchera ${ }^{3}$

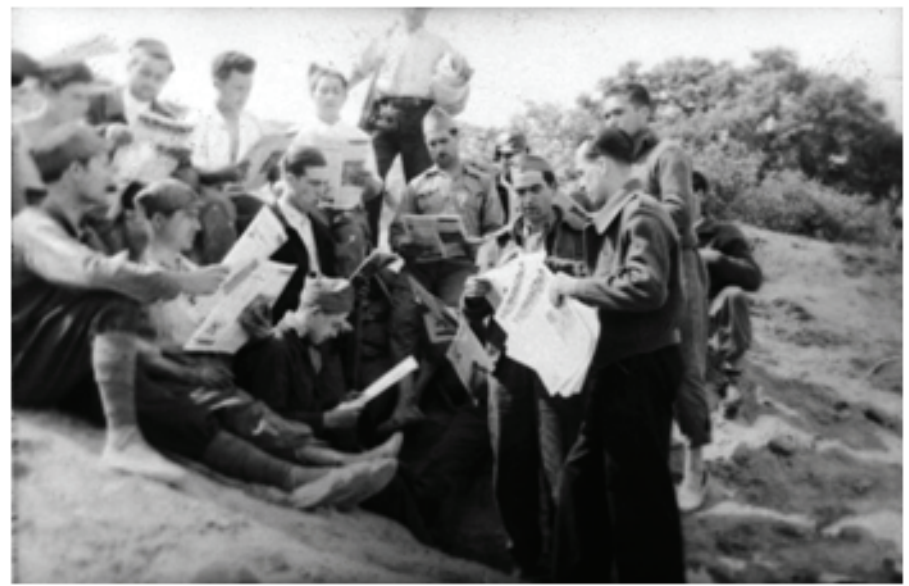

Figura 2. Trinchera ${ }^{4}$

${ }^{3}$ Fondo Fotográfico Martín Santos Yubero. Archivo Regional de la Comunidad de Madrid, Sig. 30943.028.

${ }^{4}$ Fondo Fotográfico Martín Santos Yubero. Archivo Regional de la Comunidad de Madrid, Sig. 30946.1. 


\section{b. RETAGUARDIA}

Tabla II. Asuntos retratados en la retaguardia

\begin{tabular}{|l|l|}
\hline Asunto & Núm. de fotografías \\
\hline Documentación y billetes & 8 \\
\hline Política. Discursos & $\mathbf{1 5 6}$ \\
\hline Política. Conferencias & 101 \\
\hline Política. Inauguraciones y nombramientos & 33 \\
\hline Política. Reuniones y visitas & 49 \\
\hline Medios de transporte. Tranvías & 3 \\
\hline Medios de transporte. Ambulancias & 9 \\
\hline Personajes & $\mathbf{2 2 1}$ \\
\hline Trabajo mixto & 5 \\
\hline Ataque enemigo & 3 \\
\hline Destrozos & 66 \\
\hline Parapetos & 28 \\
\hline Víctimas & 11 \\
\hline Hombre. Trabajo & $\mathbf{2 4 0}$ \\
\hline Mujeres. Trabajo & $\mathbf{2 3 1}$ \\
\hline Mujeres. Vida en la calle & 55 \\
\hline Mujeres. Asueto y entretenimiento & 4 \\
\hline Niños & 58 \\
\hline Cultura & $\mathbf{1 3 9}$ \\
\hline Espacios comunes & $\mathbf{4 5 2}$ \\
\hline
\end{tabular}

El espacio de la retaguardia es el más retratado por Yubero. Hemos dividido las instantáneas en 20 categorías temáticas diferentes en las que destacan, por número de fotografías, "Cultura", "Política.

Discursos", "Personajes", "Mujeres. Trabajo", "Hombre. Trabajo", y "Espacios Comunes", que hace referencia a vida en la calle, de ahí el número de fotografías. Supone un $7.4 \%, 8.3 \%, 11.8 \%, 12.3 \%, 12.8 \%$ y $24.14 \%$, respectivamente.

Estas instantáneas resultan de un extraordinario valor documental para recuperar la cotidianeidad anormal de los madrileños en la ciudad durante la contienda (Figura 3) porque su planicie visual ayuda a centrar la atención sobre el espacio y no sobre otras cuestiones más artísticas que despisten su lectura, al margen de custodiar la memoria del suceso o acontecimiento en el momento en el que se produce, como se observa en la siguiente fotografía (Figura 4) en la que un grupo de ciudadanos, refugiados en un portal, intenta ponerse al salvo justo en el momento en el que se produce el paso de aviones enemigos que, finalmente, lazan pan por la calles de Madrid el 3 de diciembre de 1938, según las notas del propio fotógrafo. 


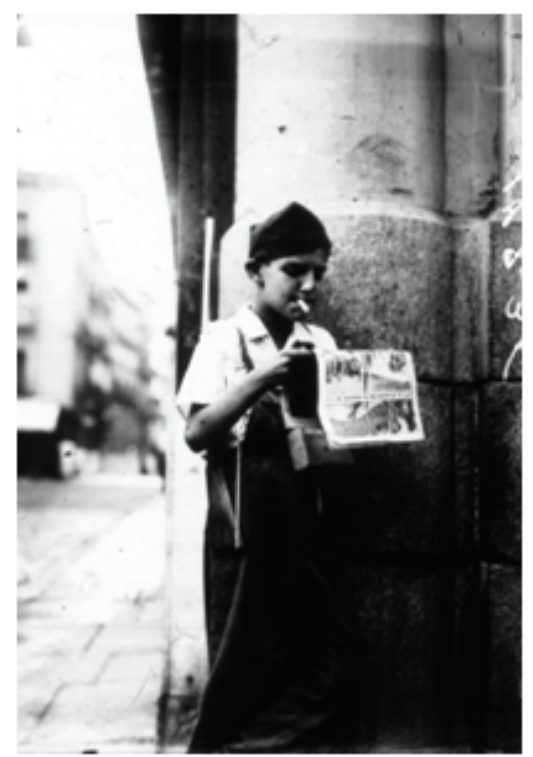

Figura 3. Niño jugando a la guerra ${ }^{5}$

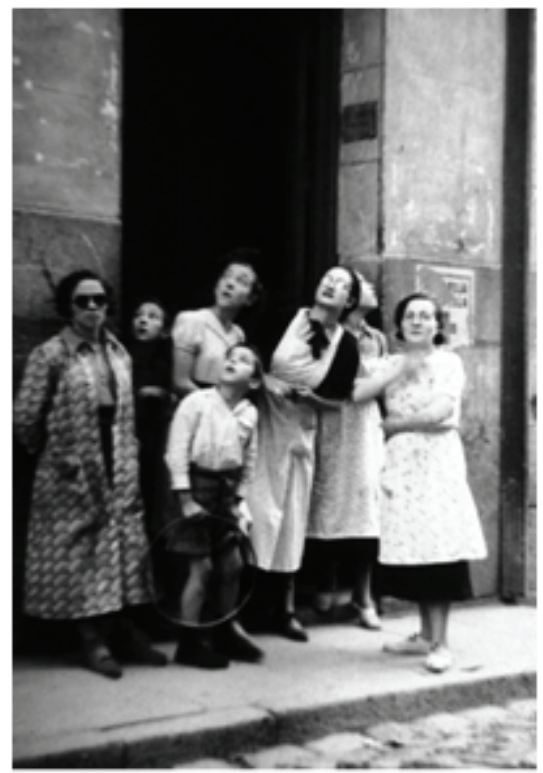

Figura 4. Llegada de aviación ${ }^{6}$

${ }^{5}$ Fondo Fotográfico Martín Santos Yubero. Archivo Regional de la Comunidad de Madrid, Sig. 44166.002. 


\section{c. RETAGUARDIA MILITAR}

Tabla III. Asuntos retratados en la retaguardia militar

\begin{tabular}{|l|l|}
\hline \multicolumn{1}{|c|}{ Asunto } & \multicolumn{1}{c|}{ Núm. de fotografías } \\
\hline Pidiendo documentación & 1 \\
\hline Prisioneros & 2 \\
\hline Desfiles y marchas & 8 \\
\hline Intendencia & 3 \\
\hline Almacenamiento y talleres de armas & 6 \\
\hline Avituallamiento & $\mathbf{3 7}$ \\
\hline Descanso del soldado & 9 \\
\hline Ocio & 3 \\
\hline Deporte & $\mathbf{4 1}$ \\
\hline Tropas en la ciudad & 9 \\
\hline Parapetos & 3 \\
\hline Mítines & 1 \\
\hline
\end{tabular}

Es el espacio menos retratado, entre otras cosas porque la retaguardia militar no es un lugar específico sino que tiene que ver con un instante en el que el espacio de la retaguardia queda invadido por la vanguardia, como se muestra en la Figura 5 en la que un grupo de milicianos carga maderas en la Puerta del Sol para su traslado al frente y así poder usarlas de combustible, o en la Figura 6 en la que una miliciana demuestra su destreza con el fusil ante la atenta mirada de un grupo de milicianos y civiles, y de fotógrafos, ya que si nos fijamos en la derecha de la imagen observamos como una mano sostiene una cámara que está retratando, al mismo tiempo que Yubero, la escena.

Del conjunto, son dos los temas que sobresalen: el avituallamiento y el deporte, que supone un $30.1 \%$ y $33.3 \%$ del total de fotografías, respectivamente.

${ }^{6}$ Fondo Fotográfico Martín Santos Yubero. Archivo Regional de la Comunidad de Madrid, Sig. 30959.001. 


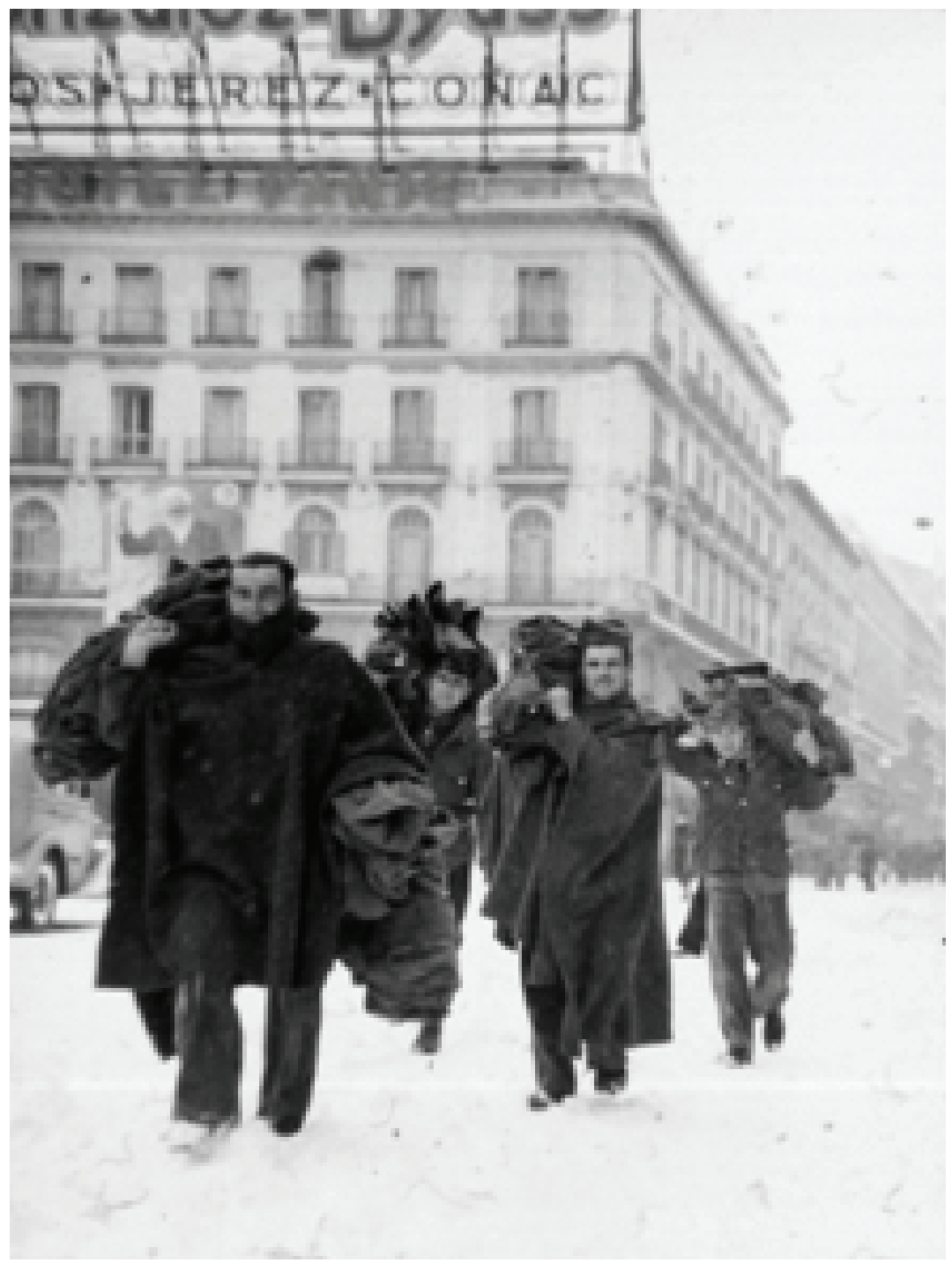

Figura 5. Milicianos en Puerta del Sol ${ }^{7}$

${ }^{7}$ Fondo Fotográfico Martín Santos Yubero. Archivo Regional de la Comunidad de Madrid, Sig. 31537.016 . 


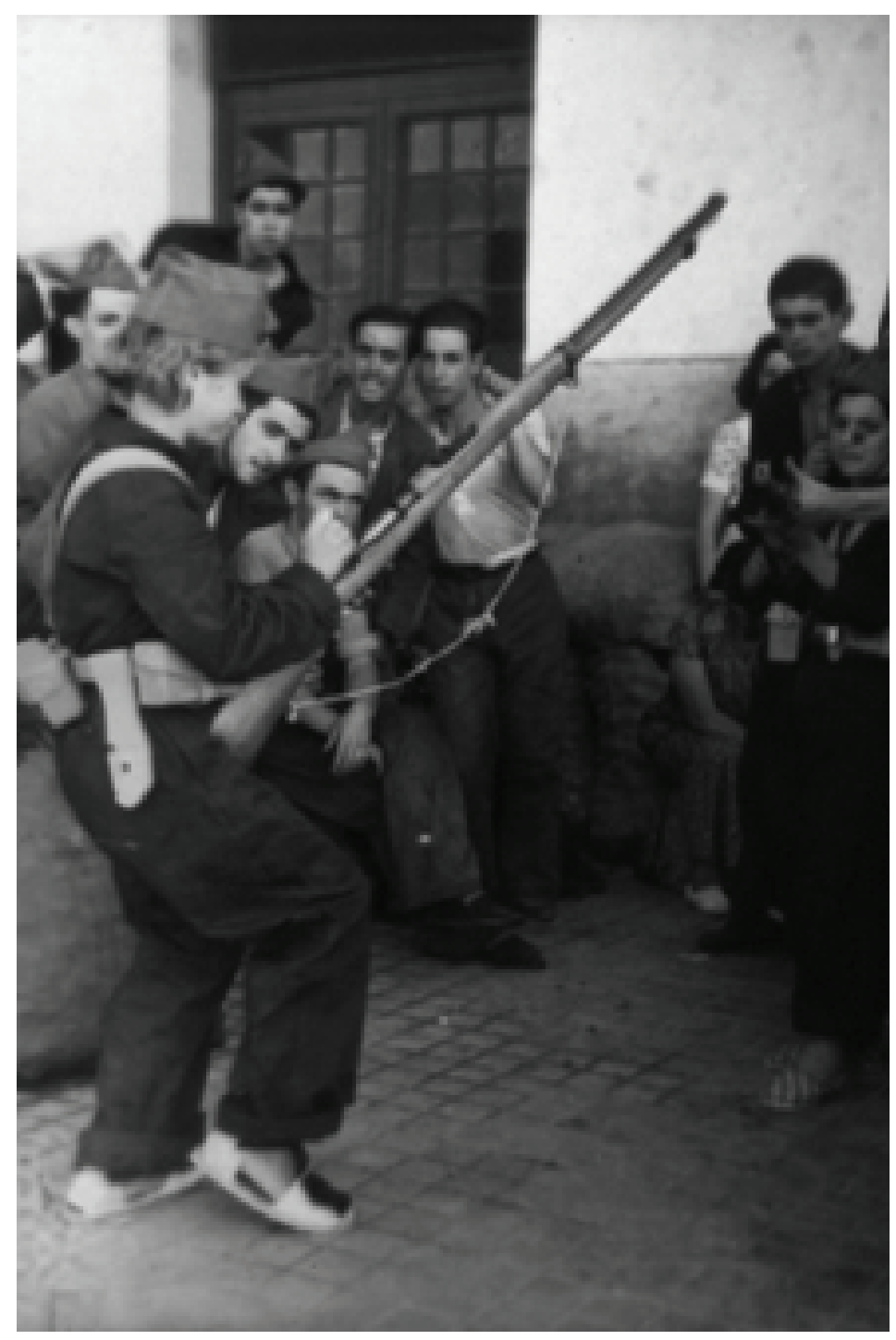

Figura 6. Miliciana en prácticas ${ }^{8}$

${ }^{8}$ Fondo Fotográfico Martín Santos Yubero. Archivo Regional de la Comunidad de Madrid, Sig. 30977.003. 


\section{TRABAJANDO CON YUBERO}

\subsection{YUBERO EN LA PRENSA. MADRID, 1936-1939}

Santos Yubero publicó en la prensa de la época con su nombre o, tras su asociación con los hermanos Benítez Casaux (quienes lo siguieron haciendo sin Yubero, como en Estampa en 1936 y 1937), con un híbrido de los dos (YuberoCasaus, Yubero-Casaux o Yubero-Benítez) que fue operativo a partir del primer otoño de guerra. $A B C$ (edición Madrid) ${ }^{9}$, Ahora, Crónica (Figura 7), La Libertad, La $V o z$ y Mundo Gráfico fueron los periódicos que emplearon sus fotografías, en las que se retrata especialmente la vida en la retaguardia, aunque fue muy reconocido su trabajo en las trincheras de Ciudad Universitaria y el barrio de Usera.

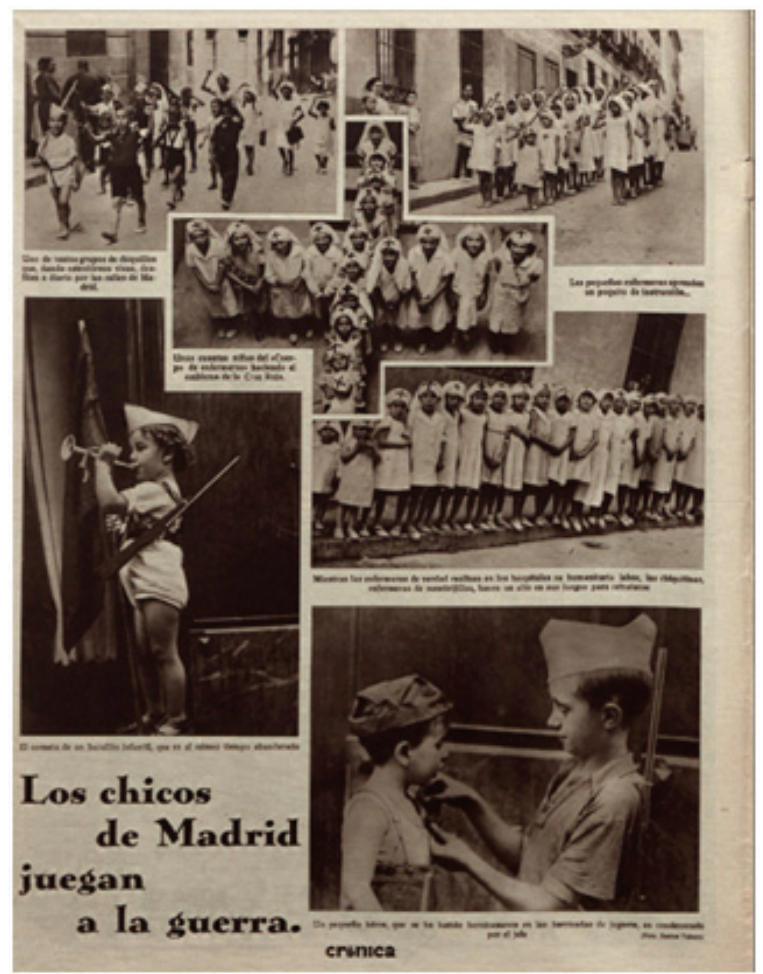

Figura 7. Reportaje publicado en Crónica, 30 de agosto de 1936

\footnotetext{
${ }^{9}$ El análisis de los periódicos y diarios ha formado parte de una de las fases de trabajo del proyecto y ha sido realizado por Jaime Cubas, Beatriz de las Heras, Víctor Mora y Magdalena Schelotto, investigadores de la Universidad Carlos III de Madrid.
} 
Se publicaron 470 instantáneas, entre las 296 fotografías firmadas en solitario por Yubero y las 174 firmadas por la agencia Yubero-Casaux, según el análisis que hemos realizado de la prensa que se conserva en la hemeroteca de la Biblioteca Nacional. Si hacemos un estudio pormenorizado por periódico, los resultamos son los siguientes:

- $A B C$, fue el diario que más instantáneas publicó de Yubero: 165 firmadas en solitario y 2 por Yubero-Casaux (publicadas el 6 y 15 de diciembre de 1936). De las de Yubero, la primera fue publicada el 6 de agosto de 1936 y la última el 28 de enero de 1938 (conviene matizar que todas se publicaron en el año 1936 menos la última y otras que lo hicieron el 7 de septiembre y el 7 de octubre de 1937).

- Ahora, de las 61 instantáneas publicadas 47 están firmadas por Yubero-Casaux y el resto por Yubero en solitario, la primera el 18 de julio de 1936 y la última el 18 de agosto de 1937.

- Crónica, se publicaron 51 fotografías firmadas por Yubero del 30 de agosto al 21 de noviembre de 1936, con la excepción de una que fue publicada el 3 de enero de 1937. Desde el 22 de noviembre todas las instantáneas fueron firmadas por Yubero-Casaux por lo que podemos pensar que la fotografía de enero fue tomada por Yubero antes de su asociación con los Casaux aunque reutilizada tras la creación de la agencia. A partir del 22 de noviembre de 1936 son 75 las instantáneas firmadas por el sello colaborativo.

- La Libertad, se publicaron 53 instantáneas firmadas por Yubero entre el 26 de julio y el 10 de noviembre de 1936.

- La Voz, se publicaron 33 fotografías firmadas por Yubero-Casaux y ninguna de Yubero en solitario, desde el 19 de marzo hasta el 29 de diciembre de 1937.

- Mundo Gráfico, a diferencia de otros periódicos, en este la colaboración fue muy puntual ya que sólo publicó en 6 días diferentes, la primera el 21 de octubre de 1936 y la última el 9 de marzo de 1938. De las 30 instantáneas, 13 están firmadas en solitario (del total, 11 en 1936 y 2 en 1938) y 17 por Yubero-Casaux, todas publicadas en 1936. Como curiosidad, el 18 de noviembre de 1936 se publicaron fotografias firmadas por Yubero y por Yubero-Casaux.

Si mostramos el resultado de este estudio de forma gráfica, el resultado es el siguiente: 
Gráfico 1. Yubero y Yubero-Casaux en la prensa, 1936-1939

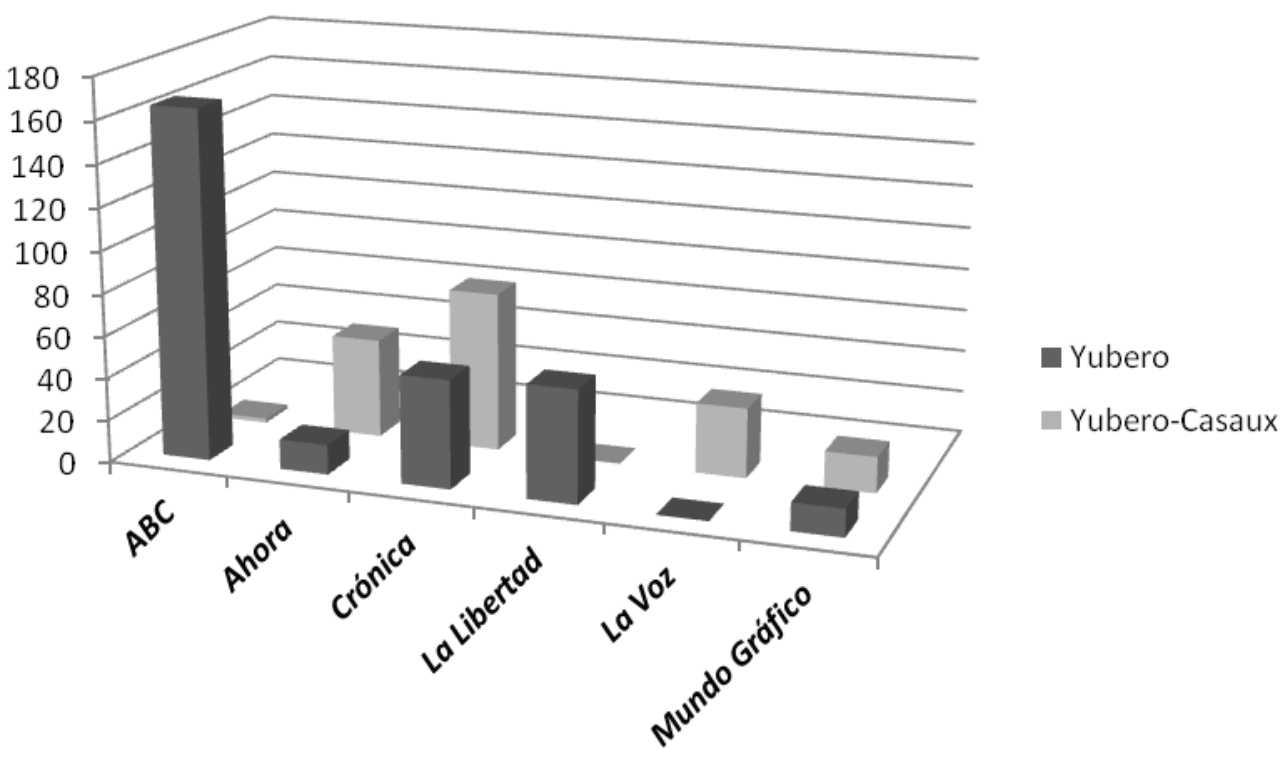

Con respecto a las fechas, la mayoría de las instantáneas fueron publicadas en el año 1936, algo normal si tenemos en cuenta que el número de fotografías en la prensa de Madrid fue disminuyendo considerablemente con el avance de la guerra debido a la propia reducción de páginas impresas por la falta de papel y tintas. Esta reducción fue aprobada, por primera vez, por la Junta de Defensa de Madrid el 10 de noviembre de 1936. Si estudiamos el número de fotografías publicadas en $A B C$, diario que más instantáneas publicó de Santos Yubero, en los seis meses que van de julio a diciembre de 1936, el diario difundió 2.463 fotografías, mientras que en los 12 meses de 1937 y 1938 (año en el que las imágenes se concentran en la portada de forma exclusiva) se publicaron 3.371 y 418 instantáneas, respectivamente (De las Heras, 2015). Finalmente, entre enero y abril de 1939 $A B C$ se ilustró con 15 imágenes publicadas el 2 de enero. Por tanto, los porcentajes de publicación disminuyen según avanza el conflicto: $39.30 \%$ en 1936 (a pesar de sólo cubrir el conflicto durante seis meses), 53.7\% en 1937 y $6.66 \%$ en 1938 (contando 12 meses de cobertura), y $0.23 \%$ en los tres meses de 1939 , tal y como mostramos de manera gráfica: 
Gráfico 2. Fotografías publicadas en $A B C$, 1936-1939

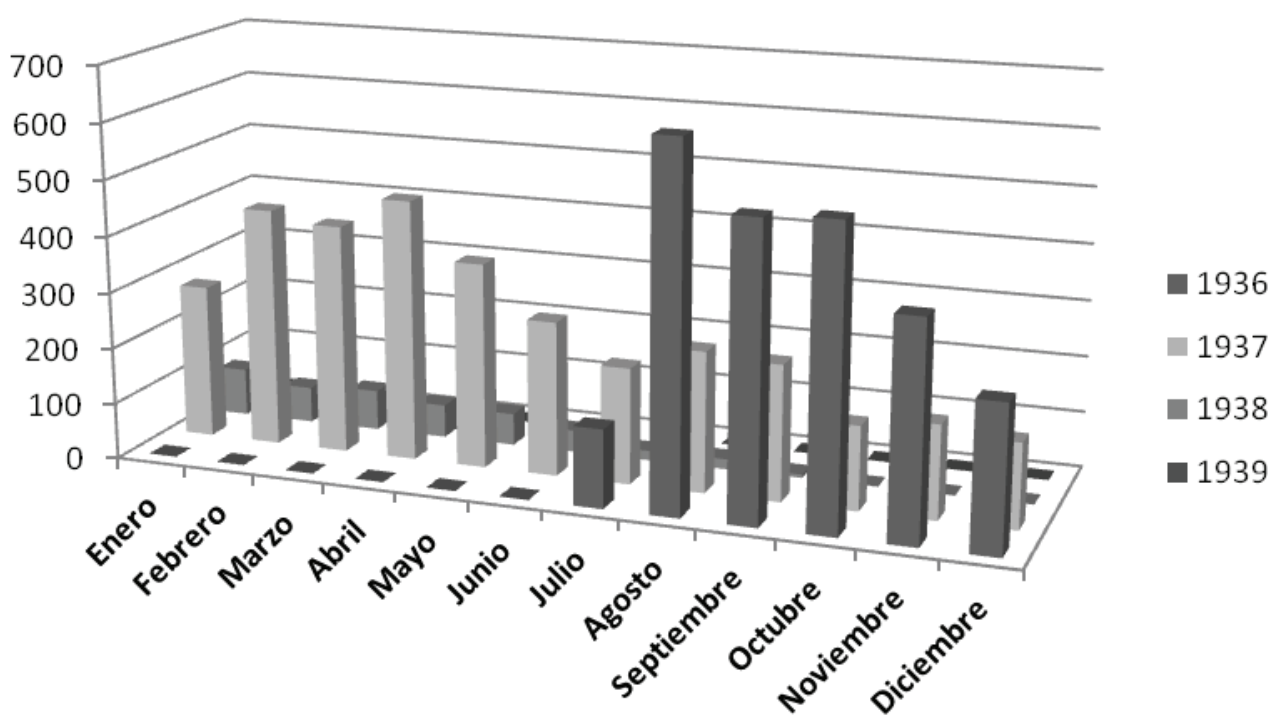

Si nos centramos en las instantáneas publicadas por Yubero/Yubero-Casaux en la prensa de la época los resultados siguen la misma línea descendente:

- $A B C: 164$ fotografías publicadas en 1936, 2 en 1937 y 1 en 1938.

- Ahora: 47 fotografías publicadas en 1936 y 14 en 1937.

- Crónica: 82 fotografías publicadas en 1936 y 44 en 1937.

- La Libertad: 53 fotografías publicadas en 1936.

- La Voz: 33 fotografías publicadas en 1937.

- Mundo Gráfico: 28 fotografías publicadas en 1936 y 2 publicadas en 1937.

Es decir, en 1936 se publicaron 374, en 193793 y en 19383 fotografías. Un $79.57 \%, 19.78 \%$ y $0.63 \%$, respectivamente, tal y como representamos a continuación: 
Gráfico 3. Fotografías publicadas por Yubero y Yubero-Casaux, 1936-1939

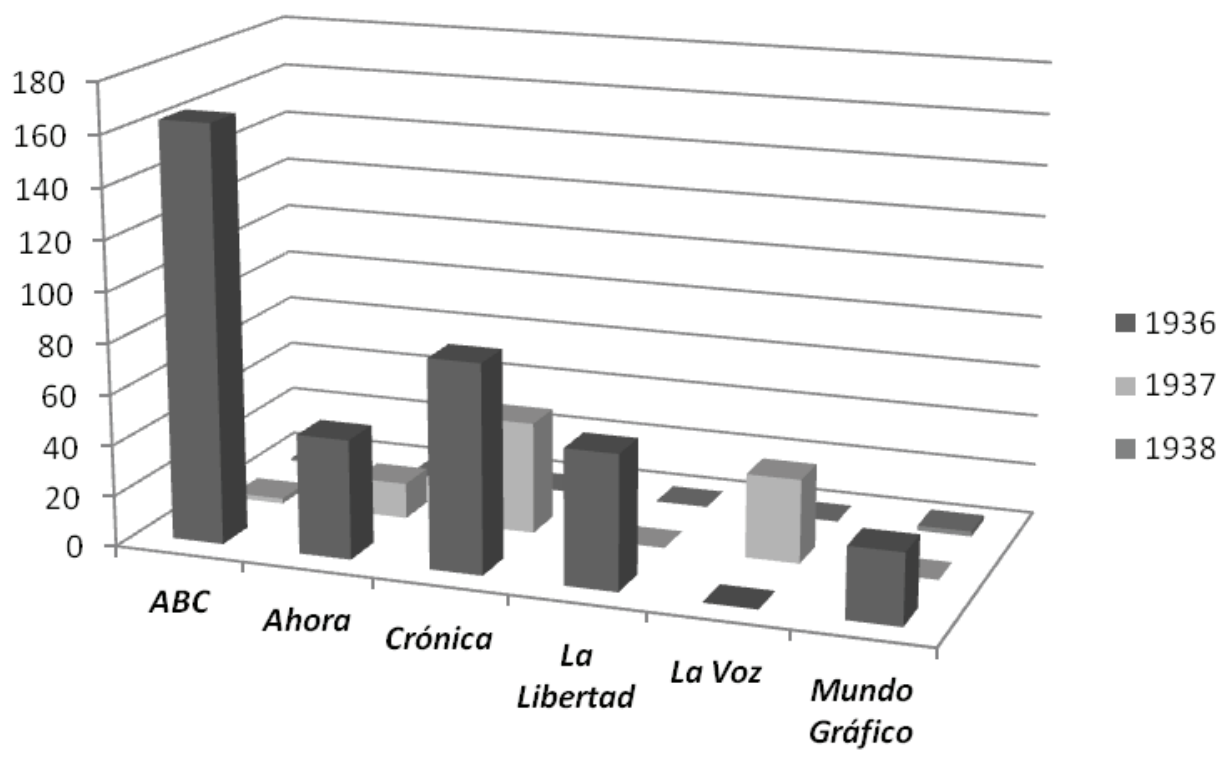

\subsection{YUBERO PARA LA HISTORIA DE LA GUERRA CIVIL ESPAÑOLA: UN ESTUDIO DE PRENSA}

Son muchas las posibilidades de trabajo que tiene la colección de Yubero desde el análisis trasdisciplinar que requiere el estudio de fotografías para recuperar la memoria del pasado, teniendo en cuenta la existencia de tres filtros diferentes: el fotógrafo, la censura política y el periódico que publicó las instantáneas. Por lo tanto nos encontramos ante la construcción de un discurso que atiende a varias dimensiones.

Vamos a poner especial atención al uso que se hizo de las imágenes de Yubero en la prensa, para lo cual, tras una primera división por fechas y temas principales, que ahora veremos, nos fijaremos en los titulares o pies que acompañan y enmarcan las fotografías, para después pasar a hablar directamente de los negativos. Fue Didi Huberman quien nos recordó que la recuperación de las imágenes para la historiografía exige un ritmo doble, una doble dimensión (Didi, 
2004: 57-62). ¿Por qué? Porque a veces se le pide demasiado o demasiado poco a la imagen, y por lo mismo que a una fotografía no podemos pedirle "toda la verdad", tampoco podemos dejarla de lado como algo sencillamente inexacto, o incompleto. Por lo tanto es interesante adentrarnos tanto en la función que se esperó que la imagen en concreto cumpliera en ese momento (coincidiendo con las coordenadas espacio-temporales del autor), como en la sustancia misma de la fotografía, su fenomenología, su especificidad. Y ese punto de vista ampliado simétricamente nos llevará a restituir las imágenes como elemento antropológico.

Partiendo de esta base es interesante elaborar un seguimiento de las fotografias de Santos Yubero en la prensa, para atender al uso concreto que se hizo de ellas en cada momento. En otras palabras, el rastreo fotográfico y el análisis de los textos que acompañan a las imágenes en los medios de comunicación analizados, nos proporcionará información sobre la intención de discurso que se pretende generar en cada momento de la contienda. La comunicación periódica siempre está al servicio de unos intereses rígidos, que no pueden permitirse mensajes abstractos, confusos o de libre interpretación, y especialmente en un contexto de evidente urgencia, como es el de la guerra. Sabemos que las ideologías crean archivos probatorios de imágenes, imágenes representativas del pasado, de la memoria (según esta idea no de memoria, sino de "instrucción" colectiva [Sontag, 2010: 7578]), imágenes que compendian ideas comunes de significación y desencadenan reflexiones y sentimientos predecibles. Así se pretende en ocasiones construir el pasado (el discurso de lo pretérito mediante imágenes que condensen significados, y creen la ilusión de consenso). Sin embargo el análisis de los negativos recuperados de Santos Yubero en contraste con su utilización en prensa nos indica que también se pretende construir así el presente.

Pero no basta con una apreciación de naturaleza tan sencilla, no basta enmarcar los negativos "en su presente", como si tal cosa fuera suficiente para situar la imagen. La imagen no sirve a la atención de "presente", porque la imagen es atravesada por la dialéctica de la mirada, que la somete a interrogantes nuevos cada vez, con independencia de la época que sea, y a la vez intrincadamente unidos a ella. Las imágenes, que poseen la cualidad aparente de inmediatez, en realidad ni son inmediatas ni fáciles de entender; ni por supuesto están "en presente", y por eso mismo son capaces de hacer visibles las relaciones de tiempo más complejas que incumben a la memoria. De tal modo que, por sí mismas, no ofrecen la visibilidad del presente que se espera del documento, por las mismas razones (o similares) por las que ningún documento para el estudio del pasado lo hace. Es necesario el ejercicio de arqueología, de mirada, recepción e interpretación.

Veamos algunos ejemplos significativos para ilustrar este proceso de análisis. 


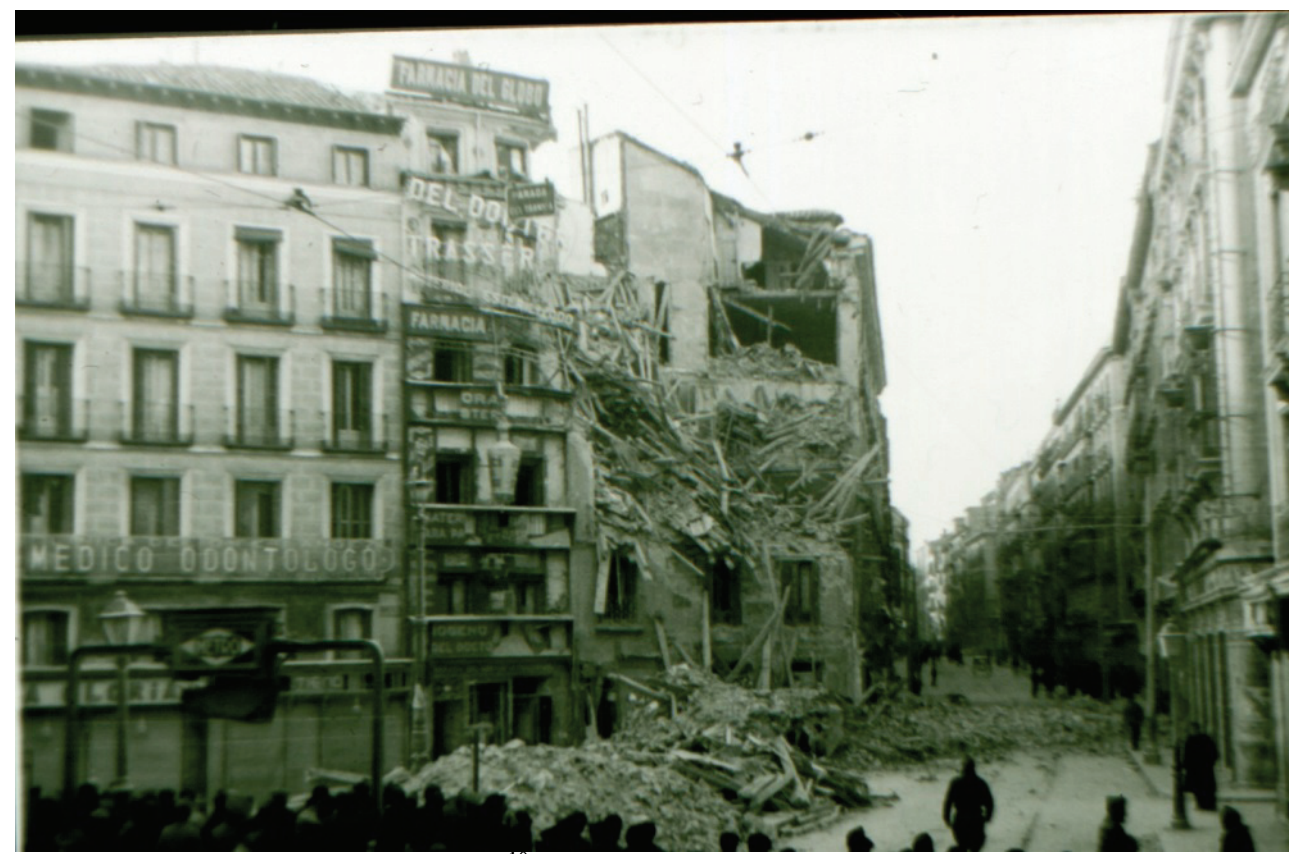

Figura 8. Bombardeo en Antón Martín ${ }^{10}$

Esta imagen (Figura 8) de la ciudad de Madrid tras un bombardeo en Noviembre de 1936, es uno de los negativos originales de Yubero recuperados. Vemos edificios parcialmente destrozados, cuyos restos acumulan escombros en las aceras y algunas personas que se acercan al escenario de la situación en la parte inferior izquierda de la imagen, y en el margen derecho una multitud de cabezas que contemplan la escena. Esta fotografía es un ejemplo muy interesante porque en este momento no se publica. La prensa no la utiliza para ilustrar la noticia de este bombardeo, sin embargo la guarda y la utiliza más adelante, en otro momento, como veremos después.

Esta otra fotografía (Figura 9), que pertenece al mismo momento de la contienda, Noviembre de 1936, nos muestra una escena enmarcada desde un gran agujero producido por el bombardeo, a través del cual vemos a algunos ciudadanos con lo que parecen azadas, palas y capazos, que utilizan para recoger los escombros producidos por la explosión.

${ }^{10}$ Fondo Fotográfico Martín Santos Yubero. Archivo Regional de la Comunidad de Madrid, Sig. 30964.3. 


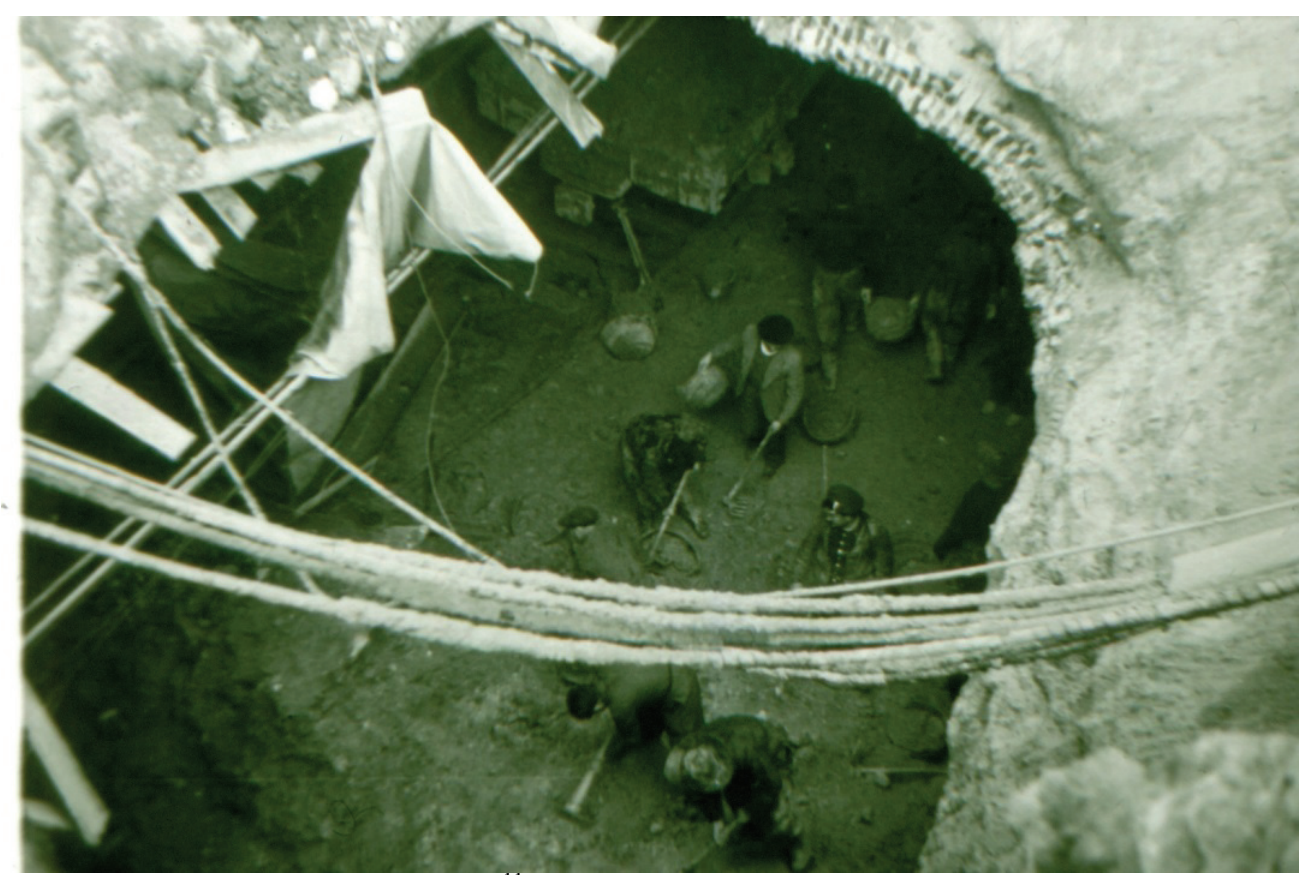

Figura 9. Socavón en la Puerta del Sol ${ }^{11}$

La siguiente sí fue publicada en prensa (Figura 10) y constituye un ejemplo gráfico de la división de lenguajes que se pretende analizar en este trabajo. Esta reproducción pertenece al diario Crónica, y acompaña con el siguiente titular: "Madrid bombardeado. Bajo la metralla facciosa, el vecindario madrileño prosigue su vida de trabajo sin pánico, sin miedo, sin temor siquiera, rivalizando en heró́smo con los combatientes que defienden la ciudad".

Un bombardeo podía ser una tragedia que formara parte de un posible cotidiano urbano, y las palabras que acompañan y enmarcan el objeto fotográfico en este caso, son instrucciones; instrucciones que dotan a la imagen de un significado que en principio no tiene. Esta imagen nos muestra un paisaje de guerra, una explosión que ha destrozado un inmueble y a varios hombres en su interior, con herramientas, trabajando para recoger los destrozos de ese ataque. Lo que se persigue entonces desde los medios de comunicación, es utilizar las palabras como una dirección de instrucción, tanto para ilustrar qué ha pasado (la noticia), como también un mensaje de instrucción, de acción. Se trata de transmitir fortaleza y

${ }^{11}$ Fondo Fotográfico Martín Santos Yubero. Archivo Regional de la Comunidad de Madrid, Sig. 30968.2 
unidad a través de una ilusión de consenso, para lo cual se utiliza la imagen, y se enmarca con palabras muy claras.

Se insiste en las mismas ideas a través de la estrategia de la repetición de significados cambiando los sustantivos (no hay miedo, no hay temor); además de generar la ilusión de unidad al comparar los esfuerzos de los vecinos de Madrid con los combatientes del frente. El mensaje que se pretende transmitir es "todos somos uno por la defensa de la ciudad", para lo cual se emplea esta imagen en la que, en este escenario de guerra, se ve a varios hombres trabajando en grupo por la recomposición del destrozo. Se muestra, por tanto, la resistencia.

Es interesante destacar que no se utilizan nunca para prensa fotografías como esta (Figura 11). Este tipo de fotografías de guerra, que no son posadas o que no tienen, como las que acabamos de ver antes, posteriores al bombardeo, un carácter de composición deliberada, poseen una carga narrativa mucho más impactante, porque congelan el momento de una acción vivida.

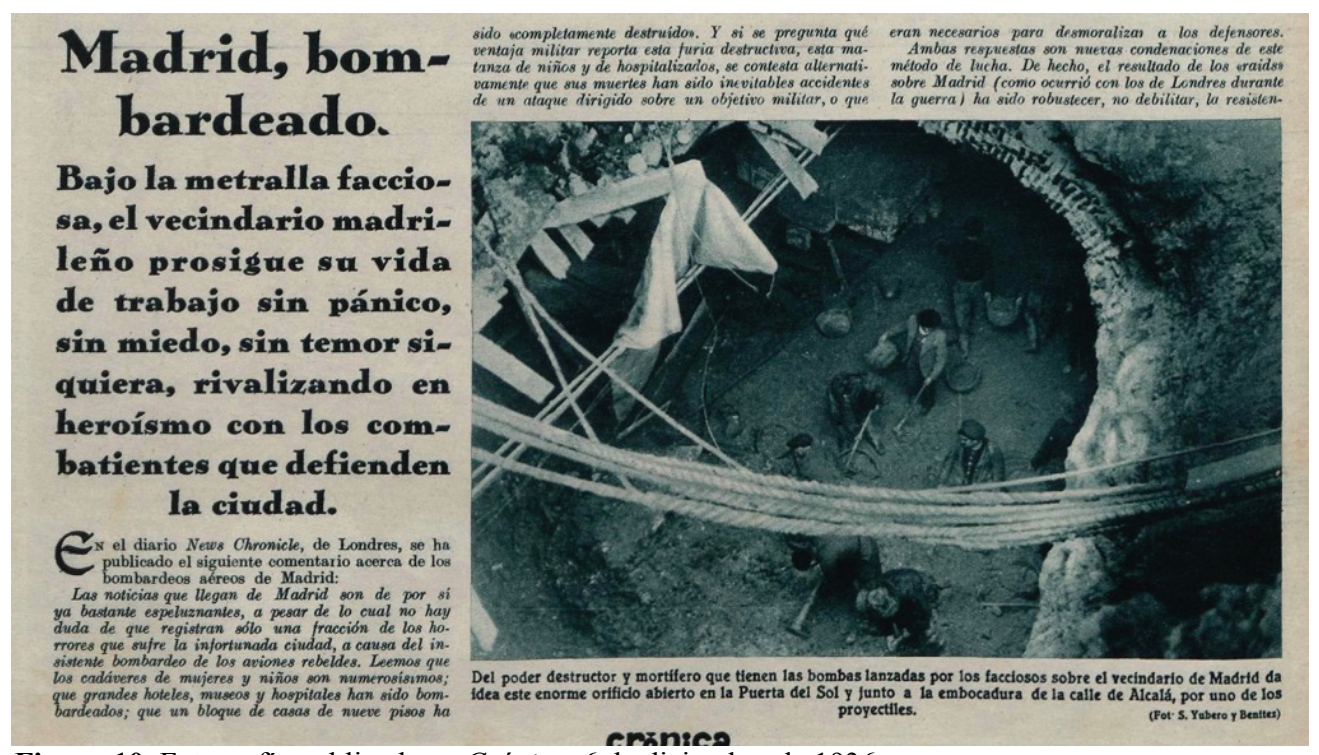

Figura 10. Fotografía publicada en Crónica, 6 de diciembre de 1936

Por tanto su contenido es difícilmente enmarcable en un texto como el anterior. Si lo que se pretende transmitir o generar es esa ilusión de consenso en la calma, la unidad y la fortaleza, es decir, insistir en la idea de que todos unidos somos más fuertes que el enemigo, no se pueden utilizar en los medios de comunicación fotografías como esta. ¿Por qué? Porque resultaría una contradicción manifiesta con la intención textual. Esta fotografía es escalofriante. Es así por lo que reconocemos de humano, de igual en la cotidianidad de los gestos. Esta imagen recoge el testigo del momento en el que se produce el bombardeo, y se retrata tanto la reacción de las personas capturadas en el negativo (que se dispersan, que 
usan el paraguas como reacción instintiva de protección, que corren, etc.), como también la actitud del fotógrafo, que no puede prepararse; no puede pararse y seleccionar el ángulo o solicitar la pose. El fotógrafo está en el momento de la misma manera que los fotografiados. Esta imagen desenfocada, movida, donde vemos ya fragmentos de la arquitectura por el suelo, en la que advertimos urgencia, miedo, huida... no puede ser publicada, lógicamente, para ilustrar un texto que pretenda transmitir calma, unidad y fortaleza; por lo tanto, no se publica. Es interesante volver a la reflexión sobre lo que es conveniente y no es conveniente mostrar en cada momento, para según qué intención de los medios, que siempre corresponde con la generación de un mensaje de acción. Es decir, del resultado que produzcan las imágenes publicadas se espera una acción colectiva, y hay momentos en los que sencillamente no se puede mostrar determinadas imágenes, simplemente porque no concuerdan, o directamente contradicen, como en este caso, el mensaje que se pretende dirigir.

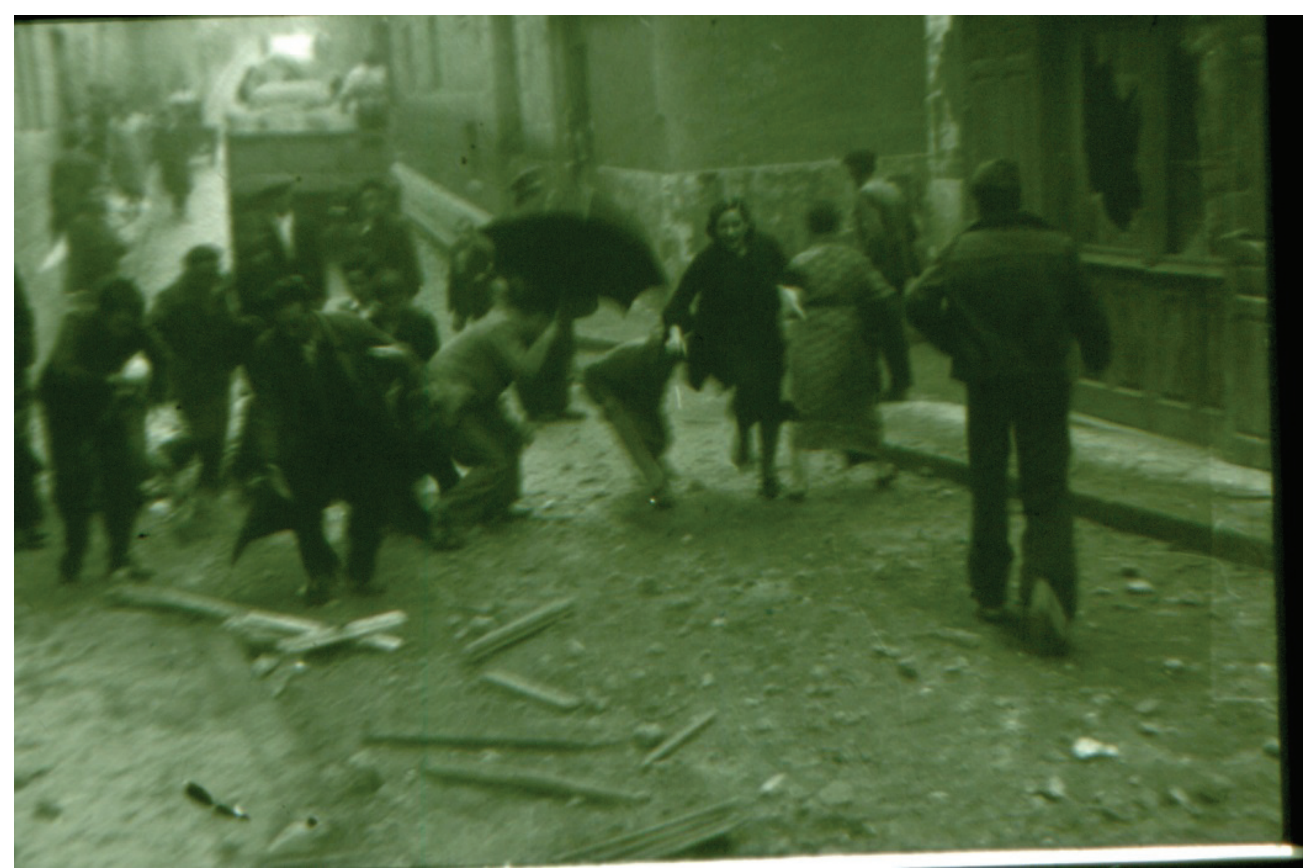

Figura 11. Explosión de obús en la calle de la Cabeza ${ }^{12}$

Si avanzamos en el desarrollo de la contienda, encontramos que la tónica informativa cambia, debido a las circunstancias producidas por la guerra. En la

${ }^{12}$ Fondo Fotográfico Martín Santos Yubero. Archivo Regional de la Comunidad de Madrid, Sig. 30981.11. 
reproducción de este reportaje (Figura 12), perteneciente al periódico Crónica, vemos la superposición de distintas imágenes con una dirección informativa que es evidentemente distinta.

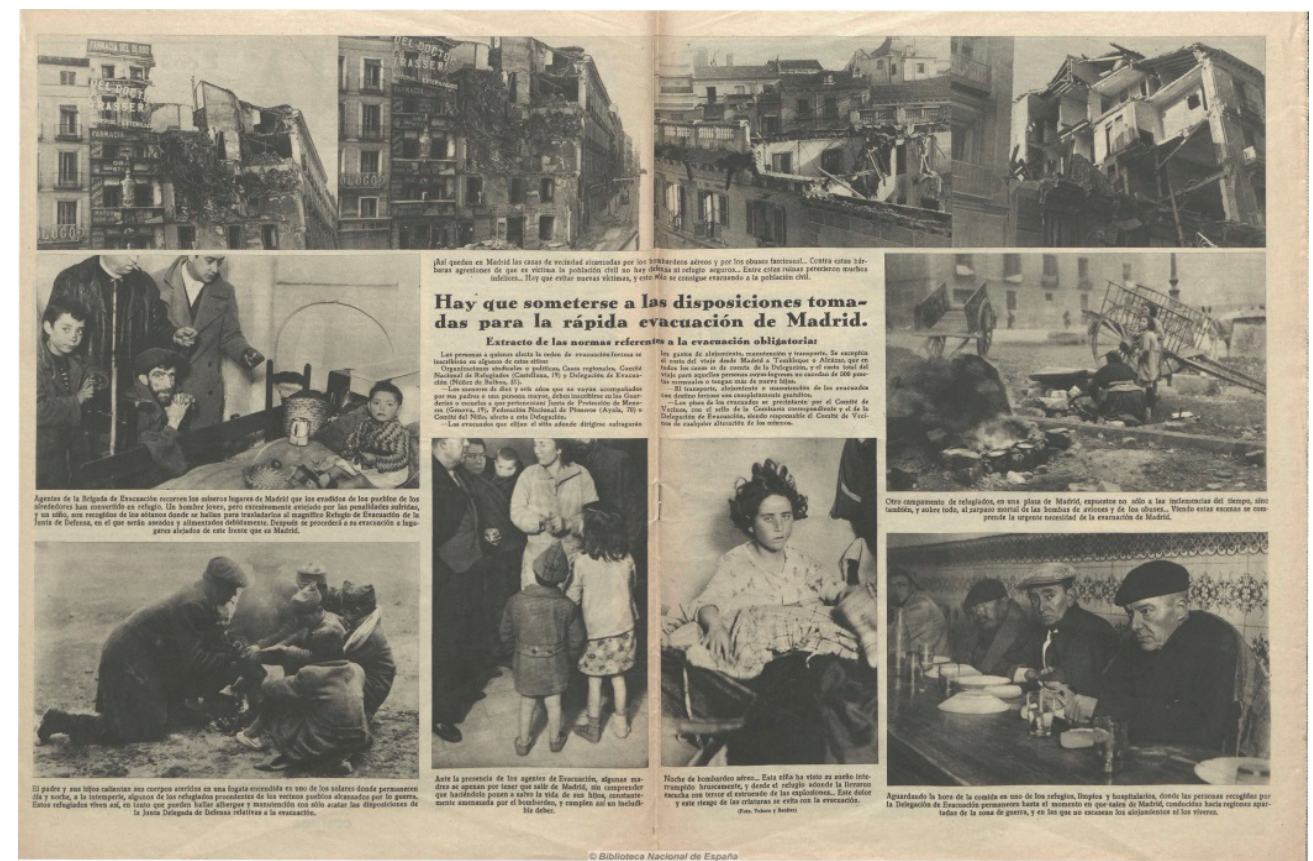

Figura 12. Reportaje publicado en Crónica, 31 de enero de 1937

La tónica que en este momento de la contienda los medios de los que nos ocupamos asumen de manera eminentemente homogénea, podemos verla en esta colección de fotografías. En esta composición vemos una complicidad de construcción, una apelación política determinada hacia una nueva generación de autoimagen que se aleja abruptamente de las ideas que hemos visto anteriormente. En la parte inferior del reportaje se ven como protagonistas fotografías de niños y niñas indefensos, también ancianos, y se retratan condiciones de miseria y de urgencia. Por ejemplo, el gesto y la mirada de la niña, retratada en la imagen central, que transmite cansancio y condiciones de debilidad y de desamparo. En otra de las fotografías vemos un hombre y cuatro niños que se unen junto a una pequeña hoguera hecha en el exterior para calentarse. En definitiva son imágenes impactantes que van dirigidas a ilustrar la misma idea; idea que, además, se repite en el texto del reportaje constantemente. Las fotografías de la parte inferior, que retratan situaciones con víctimas de la guerra, son en total 6 , y en todos los pies de fotografía se nombra y en ocasiones se repite, la palabra "evacuación", asociada a "urgente", "obligatorio", e "inmediato". Para la construcción de esta nueva autoimagen se aplica el impacto fotográfico, no es un reportaje, por tanto, meramente informativo de las características o instrucciones para la evacuación, 
ya que mediante las imágenes fotográficas se interfiere en el imaginario colectivo, alterando la conciencia y generando nuevos arquetipos. El abuso de la imagen como elemento de interpelación a la conciencia lo vemos reflejado en el empleo de fotografías de niños en estas condiciones, algo que intercede directamente en la responsabilidad del adulto, que es el destinatario potencial del reportaje. Es un conjunto fotográfico que, en sí mismo, llama a la acción, ilustra, en otras palabras, la urgencia de la evacuación, y para ello utiliza el lenguaje visual propio de la propaganda de guerra, en tanto uso (y abuso) de las imágenes como elemento que interpela, señala y, en cierta medida, responsabiliza. En la parte superior del reportaje lo que vemos son imágenes del paisaje urbano (Figura 13), fragmentos de la ciudad parcialmente destrozada por los bombardeos.

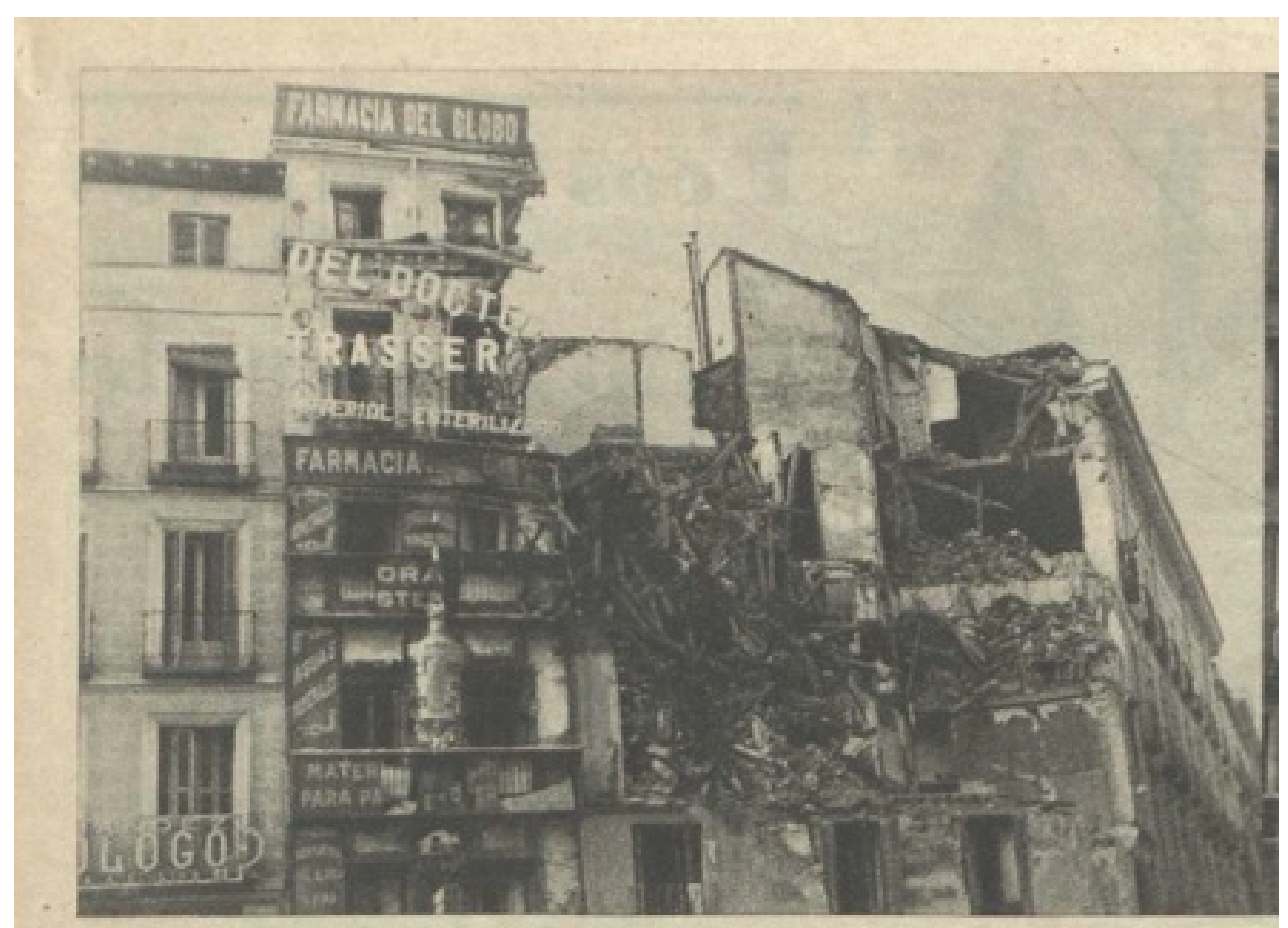

Figura 13. Fotografía publicada en Crónica, 31 de enero de 1937

El titular que enmarca estas fotografías de los edificios derruidos es el siguiente: "Así quedan en Madrid las casas de vecindad alcanzadas por los bombardeos aéreos y por los obuses facciosos. Contra estas bárbaras agresiones de que es víctima la población civil no hay defensa ni refugio seguros. Entre estas ruinas perecieron muchos infelices. Hay que evitar nuevas víctimas, y esto solo se consigue evacuando a la población civil." 
Lo que vemos es el detalle a distancia de la destrucción producida por los bombardeos. Como podemos comprobar los marcos de selección fotográfica, efectuados por los responsables del montaje del reportaje en Crónica, limitan la imagen de los edificios a su fachada y no muestran las aceras o calzadas de las calles. Esta fotografía pertenece a una serie de imágenes de Santos Yubero, que ya vimos anteriormente (Figura 8).

Como podemos comprobar a simple vista es una imagen manipulada, recortada. Se ha intervenido la fotografía para mostrar el detalle del edificio derruido, sin embargo es interesante advertir que lo que se censura en este caso es la parte inferior, en la que ya hemos comentado que se puede ver a algunas personas que se acercan al escenario de la situación en la parte izquierda de la imagen, y en el margen derecho una multitud de cabezas que contemplan la escena. ¿Por qué no se publica la imagen completa? ¿Por qué se censura al grupo de personas?

En el reportaje sobre la urgencia de la evacuación las imágenes que ilustran Madrid como escenario, han de transmitir la idea de una ciudad destrozada e inhabitable que anima a la evacuación. El paisaje urbano ha de ser el paisaje de la destrucción irrecuperable, lejos de la idea que se pretendía mostrar meses atrás, de unidad y fuerza para la recomposición. Ahora lo que interesa mostrar es lo contrario: la imposibilidad de recomposición, y por eso no se muestra la posibilidad de grupo. Es decir, las fotografías que se superponen para enmarcar la noticia son particulares. Vemos situaciones particulares de personas o pequeños grupos identificables como historias personales, de tal modo que apelan al individuo de una manera distinta.

La fotografía original, frente a la reproducción manipulada por selección de contenido, podría apelar a la colectividad para la resistencia, o para la reconstrucción de lo perdido a través del trabajo en grupo. Ya hemos visto otras fotografías de esta serie utilizadas para transmitir la ilusión de consenso en la unidad y en la fortaleza, es decir, dirigidas a estimular una colectividad organizada; pero en el momento de la evacuación se quiere huir de tales ideas y apelar directamente a la emoción particular, personal, singular, por lo tanto no hay colectividad representada como un genérico, y lo que se muestra es el paisaje urbano destrozado sin representación humana.

Fue Boris Kossoy quien relacionó de manera muy reveladora para el uso de la imagen fotográfica como documento los conceptos de "evidencia documental" y "construcciones de realidades". Dentro del apartado "Fotografía y memoria" (Kossoy, 2014: 141-143), Kossoy advierte que la llamada evidencia documental de la fotografía es la más astuta estratagema sobre la cual se apoya el sistema de representación fotográfica.

Estos ejemplos constituyen una breve selección del trabajo de análisis efectuado tomando en consideración los negativos y placas de Yubero que estaban en potencia destinados a olvidarse, junto con los seleccionados para su publicación en prensa; los cuales, como hemos visto, son utilizados en momentos diversos, y 
manipulados en función de la intención discursiva de cada situación. Las fotografías en sí mismas destilan una carga narrativa con una implicación claramente distinta, algo que quizá simplemente se deba a la carencia de contaminación discursiva que ejercen los medios de comunicación, que dirigen e instruyen la mirada, para crear así la ilusión de consenso y el imaginario efectivo.

"Los reportajes no tienen otra intención", nos diría Benjamin, "que eliminar la autenticidad potencial de la fotografía, y sus clichés visuales no tienen otro efecto que el de suscitar por asociación, en el que mira, clichés lingüísticos." A este efecto es al que Benjamin llamaría "analfabetismo de la imagen" (Benjamin, 2007: 377-402).

Sin embargo, en esta dialéctica obligatoria a la que nos somete la imagen cuando la interrogamos, la sensación que nos produce la mirada implicada de Yubero en el escenario, en la situación fotografiada, dista mucho de ese roce leve de la realidad que se distingue de sus "poco estilosas" se ha dicho, fotografías suyas en prensa. Por tanto, la recuperación del Madrid de la guerra a través de la mirada de Santos Yubero, es en realidad la recuperación de un Madrid poliédrico, intervenido por una mirada múltiple que atendía a múltiples intereses, desde los relativos a de los medios de comunicación, con diverso resultado según el momento y la temática, hasta sus propios intereses como fotógrafo, experimentador de las imágenes y observador.

\section{CONCLUSIONES}

La recuperación de los negativos que Santos Yubero tomó durante la Guerra Civil, y el seguimiento de aquellos que fueron publicados en prensa, nos proporciona nueva información, desde múltiples dimensiones, a la hora de enfrentarnos a la (re)construcción de un discurso historiográfico sobre este período. Hemos visto el resultado del análisis a partir del uso de las imágenes "en presente" en los medios de comunicación, y el empleo de las palabras como método de instrucción colectiva y de dirección de la mirada; trabajo complementado con los negativos no publicados, es decir, los destinados potencialmente, en su presente, al olvido. Por tanto, en este proceso de investigación, además del propio análisis fenomenológico de la fotografía como objeto, cobran especial relevancia conceptos tales como montaje, interpretación, reasignación, significado, mistificación $\mathrm{y}$, evidentemente, memoria. La recuperación de los negativos de Yubero nos señala, en gran medida, "todo lo que no", todo lo que quedó fuera de esa selección destinada a construir el presente en los medios de comunicación, y nos proporciona por lo tanto otros fragmentos con los que poder completar el arco de tiempo (Rodríguez de las Heras, 2009: 19-35) sobre el que pretendemos trabajar. Cabe preguntarse, por tanto, si todo el contenido de significados que se condensa en una imagen, y que no nos detenemos nunca a analizar porque se codifica y descodifica en nuestro imaginario de manera prácticamente automática, no es, quizá, resultado de un ejercicio de selección 
previo muy cuidadoso y muy concienzudo, en busca de determinados significados y en detrimento de otros. Significados que, como hemos visto, tratan de construir, y efectivamente construyen, la autoimagen social hegemónica. Para la creación de ese consenso se utilizan las fotografías y el discurso, como sabemos, se construye también con imágenes.

Esta cuestión resulta siempre una línea interesante para la investigación y la reflexión, y queda abierta para futuros trabajos. Y en relación a las ideas de las imágenes como soporte de mensajes relevantes para la identidad, la memoria y el discurso, resulta sugerente retomar a Benjamin para abordar la cuestión fotográfica de Yubero, su enfoque, su propia mirada. La mirada, la selección, el sesgo del ojo fotográfico, nos habla también del propio interés del fotógrafo, de su universo creativo. Benjamin hablaba de "desmaquillar" la realidad, de la capacidad específica de la imagen como objeto, en tanto nos ofrece una experiencia, una enseñanza y una marca fundamental de autenticidad. Esta capacidad fotográfica se destaca en relación a su implicación, no "con" el hecho fotografiado, sino "en" el hecho en sí. Muchos de los negativos de Yubero se distinguen como trabajos, lo que podríamos llamar "retratos de encargo", es decir, el interés de creación de realidades en función del interés de generación de titulares, ejemplos de lo cual hemos visto unos cuantos. Pero otros negativos se distinguen por una implicación distinta, y tienen más que ver con una experimentación personal del fotógrafo, que destaca y se traduce en imágenes de naturaleza muy diferente.

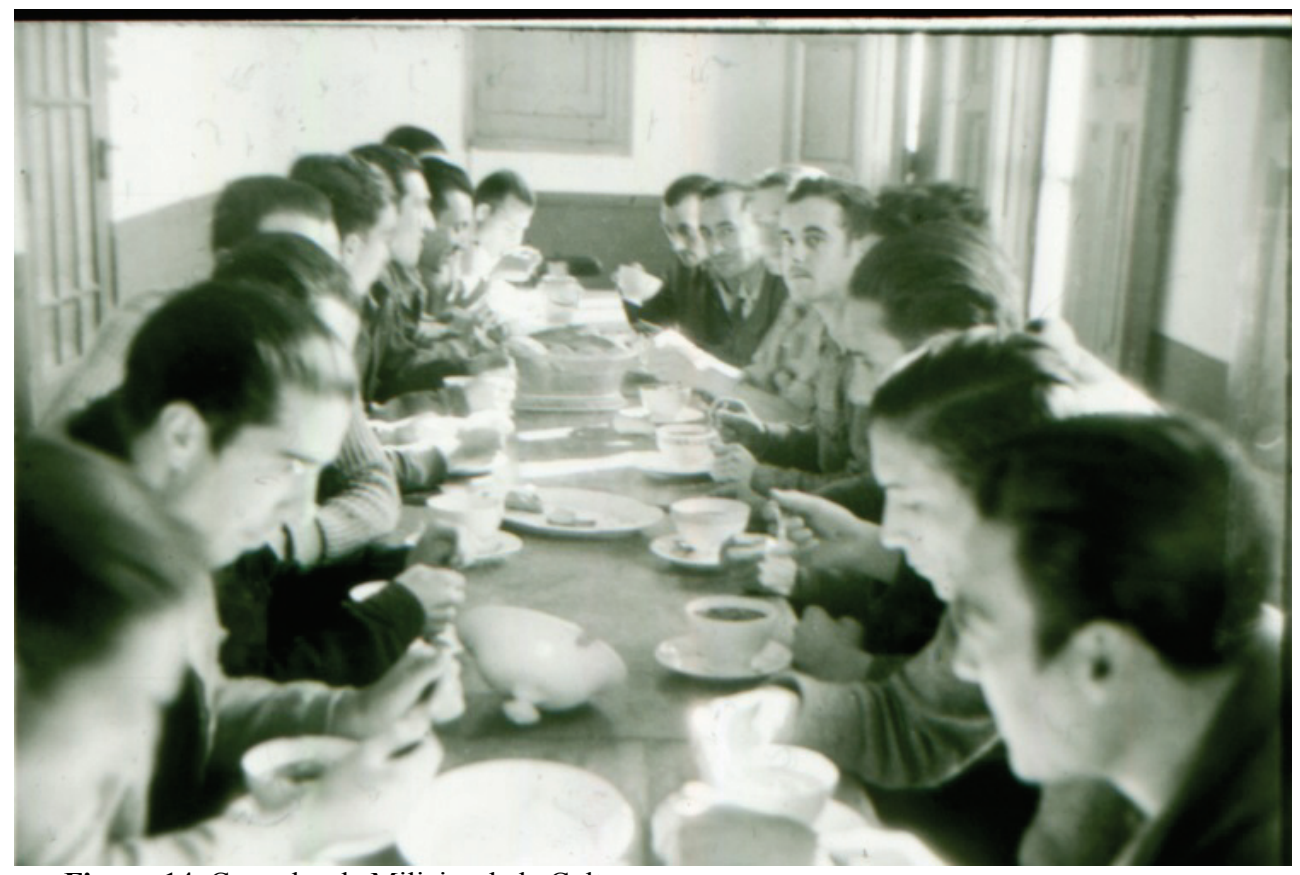

Figura 14. Comedor de Milicias de la Cultura 
Esta fotografía (Figura $14^{13}$ ), por ejemplo, muestra claramente (todas lo hacen) la unión de esos dos atributos que hacen contradictoria a la imagen como objeto, ya que su crédito de objetividad es indiscutible, pero al mismo tiempo, necesariamente, tiene siempre un punto de vista. Es en las relativas a esta división, las descartadas, las destinadas en potencia a la invisibilidad, donde encontramos el modo personal del hacedor de imágenes, la subjetividad propia de Yubero. Este enfoque es, quizá, propio de la experimentación, y de la carrera profesional al margen de cualquier escuela de fotografía. La mayoría de los fotógrafos de esta época, y más en estas circunstancias, aprendieron trabajando, y durante ese camino de aprendizaje se aprecia la implicación particular de Yubero en el hecho fotografiado. Es interesante rescatar el tema de la implicación dado que siempre se ha dicho sobre él, además de que era el gran fotógrafo sin estilo, que carecía de implicación política, y esto es solo cierto a medias, pero desde luego no estaba implicado con la República durante la guerra, dentro del activismo o la militancia, y por esta razón, además de por su evolución posterior, la recuperación de su memoria fotográfica ha sido tomada con cierta reticencia.

Algunos negativos transmiten, como este, esa implicación consciente "en" el hecho fotografiado. Aquí Yubero está en el lugar, y mira sabiéndose ahí, y sabiéndose mirado, pero sin mayor intención que la de congelar la cotidianidad; de tal modo es así que pudo, quizá, fundirse en el momento, como explica Benjamin, fundirse en ese escenario extraordinario convertido en cotidiano, en el que vemos que solo uno de los retratados, al fondo del marco, ha advertido el instante fotográfico, y observa al fotógrafo. Este ejercicio de fundirse "en las cosas" es a lo que refiere la sentencia acerca del mirar a la fotografía como retrato de una enseñanza, o de una experiencia. Una dialéctica temporal que mantiene y hace perdurar una información que no está en la construcción de discurso de carácter marcadamente técnico. Es interesante analizar la trayectoria de las imágenes en la prensa, con todo lo que conlleva, sus amputaciones, recortes, manipulaciones y también sus pertinentes instrucciones escritas, porque nos proporciona las pautas de la construcción del imaginario, o al menos de la intención, además de servir como cronología de acontecimientos.

Sin embargo el "fundirse en las cosas" propia de la subjetividad personal de Yubero como hacedor de imágenes, nos da una visión tangente, independiente, a la intención discursiva dominante. Podríamos decir que va más hacia un interés casi artístico, de la fotografía como disciplina, como método de expresión. Realizó en su mayoría trabajos para ilustrar noticias, como decíamos, pero parece que tenía un interés más allá de las noticias correspondientes, o los ejercicios de propaganda encargados; un interés en capturar imágenes.

\footnotetext{
${ }^{13}$ Fondo Fotográfico Martín Santos Yubero. Archivo Regional de la Comunidad de Madrid, Sig. 309551.042
} 
No parece carencia de estilo, aunque sí una carencia de implicación política, o, si se quiere, un mero "deber cumplido" de cara a la ilustración de noticias. Sin embargo nos quedan las otras, las olvidadas, que parecen, insistimos, invitarnos a un revelado distinto, implicado sabiéndose mirado, fotografiando siendo escrutado por el momento mismo, y también por sus protagonistas.

\section{REFERENCIAS BIBLIOGRÁFICAS}

BENJAMIN, Walter (2007), "Pequeña historia de la fotografía" en Obras II. Madrid: Abada, pp. 377-402.

CARNICERO ARRIBAS, Manuel (2003). "Los Archivos de la Comunidad de Madrid", en Tst: Transportes, Servicios y Telecomunicaciones, no 7, pp. 149-198.

DE LAS HERAS, Beatriz (2012). Fotografia e Historia. El testimonio de las imágenes. Madrid: Creaciones Vicent Gabrielle.

DE LAS HERAS, Beatriz (2015). Fotografiar en una ciudad sitiada. Madrid, 19361939. Madrid: Ministerio de Economía y Competitividad.

DIDI HUBERMAN, Georges (2004). Imágenes pese a todo. Barcelona: Paidós Ibérica.

DUPLÁ DEL MORAL, Ana (2008). Los fondos fotográficos en el Archivo Regional de la Comunidad de Madrid: Breve descripción de los mismos y diferentes criterios en torno a la cuestión. En: Terceras Jornadas Archivo y Memoria (Madrid, 21 y 22 de febrero de 2008). Madrid: CSIC-Fundación de los Ferrocarriles Españoles.

KOSSOY, Boris (2014). Lo efímero y lo perpetuo en la imagen fotográfica. Madrid: Cátedra.

LÓPEZ MONDÉJAR, Publio (2010). Santos Yubero: crónica fotográfica de medio siglo de vida española. Madrid: Lunwerg.

LÓPEZ MONDÉJAR, Publio (2011). "El ojo público de Santos Yubero". Descubrir el arte, $\mathrm{n}^{\circ} 143$, pp. 66-71.

OFICINA MUNICIPAL DE INFORMACIÓN SOBRE LA CIUDAD (1929). Información sobre la ciudad. Memoria año 1929. Madrid: Ayuntamiento de Madrid. RODRÍFUEZ DE LAS HERAS, Antonio (2009). "Metodología para el análisis de la fotografía histórica". Espacio, Tiempo y Forma, Serie V, Historia Contemporánea, $\mathrm{n}^{\circ} 21$, pp. 19-35.

RODRÍGUEZ REY, Noelia (2013). Fondos y colecciones fotográficos del Archivo y Biblioteca Regional de la Comunidad de Madrid. Descripción y análisis. Madrid. Universidad Complutense de Madrid

SÁNCHEZ VIGIL, Juan Miguel; OLIVERA ZALDUA, María (2014). Fotoperiodismo y República. Madrid: Cátedra.

SÁNCHEZ VIGIL, Juan Miguel (2013). La fotografia en España. Otra vuelta de tuerca. Gijón: Trea.

SONTAG, Susan (2010). Ante el dolor de los demás. Barcelona: Mondadori. 